\title{
Structure, diversity, and spatial patterns in a permanent plot of a high Restinga forest in Southeastern Brazil
}

\author{
Renato Augusto Ferreira de Lima ${ }^{1,6}$, Alexandre Adalardo de Oliveira ${ }^{2}$, Adriana Maria Zanforlin Martini ${ }^{2,3}$, \\ Daniela Sampaio ${ }^{4}$, Vinícius Castro Souza ${ }^{5}$ and Ricardo Ribeiro Rodrigues ${ }^{5}$
}

Recebido em 23/07/2010. Aceito em 20/06/2011

\begin{abstract}
RESUMO
(Estrutura, diversidade e padrões espaciais em uma parcela permanente de floresta alta de Restinga no Sudeste do Brasil) Nós investigamos a estrutura, diversidade e distribuição de espécies arbóreas em uma parcela de 10,24 ha de uma floresta alta de Restinga (FAR) no Sudeste do Brasil. Nós amostramos 15.040 indivíduos pertencentes a 45 famílias, 87 gêneros e 116 espécies (densidade $=1.468$ árvores ha ${ }^{-1}$, e área basal $=28,0 \mathrm{~m}^{2} \mathrm{ha}^{-1}$ ). A riqueza média foi menor que outros tipos de florestas tropicais e outras FAR amostradas em menor intensidade, provavelmente pela juventude e hidromorfia dos solos na área de estudo. A densidade, área basal, composição e diversidade arbórea variaram consideravelmente de acordo com a classe de tamanho considerada. A parcela estudada teve uma densidade similar a outras florestas tropicais, mas com menor área basal (menos indivíduos $>60 \mathrm{~cm}$ de diâmetro) e maior densidade de árvores pequenas. Fustes múltiplos não foram frequentes (11\% dos indivíduos), mas foram comuns entre as espécies ( $74 \%$ das espécies). A distribuição espacial foi predominantemente agregada, um padrão comum a outros tipos de florestas tropicais. Além do substrato arenoso, a parcela estudada e outras florestas de areia branca do mundo tiveram padrões muito similares de estrutura, riqueza e diversidade. Assim, consideramos a FAR como um subtipo evidente de floresta de areia branca.
\end{abstract}

Palavras-chave: classes de tamanho de árvores; Floresta Atlântica, fustes múltiplos; riqueza de espécies

\begin{abstract}
(Structure, composition, and diversity of a high Restinga forest in the Southern Atlantic Forest) We assessed the structure, diversity and distribution of tree species in a 10.24-ha permanent plot of high Restinga forest (HRF) in southeastern Brazil. We sampled 15,040 individuals belonging to 45 families, 87 genera and 116 species $\left(\right.$ density $=1,468$ trees ha- ${ }^{-1}$, and basal area $\left.=28.0 \mathrm{~m}^{2} \mathrm{ha}^{-1}\right)$. Mean richness was lower than other types of tropical forests and other HRFs that have been less intensively sampled, which is probably due to the younger age and hydromorphy of the soils in the study site. Tree density, basal area, species composition, and diversity all varied considerably depending on the size class considered. The studied plot had a density similar to other tropical forests but with a smaller basal area (fewer individuals $>60 \mathrm{~cm}$ in diameter), and higher density of smaller trees. Multi-stemmed individuals were not frequent (11\% of the trees), though they were widespread among species (74\% of the species). Spatial distribution was predominantly clumped, a pattern common to other types of tropical forests. Besides growing over white-sand soils, the PEIC plot and other white-sand forests of the world also had very similar patterns of community structure, richness and diversity. Therefore, we consider the HRF as a recognizable subtype of white-sand forest.
\end{abstract}

Key words: Atlantic Forest; multi-stemmed trees; species richness; tree size classes

1 Universidade de São Paulo, Instituto de Biociências, Programa de Pós-Graduação em Ecologia, São Paulo, SP, Brazil

2 Universidade de São Paulo, Instituto de Biociências, Departamento de Ecologia, São Paulo, SP, Brazil

3 Universidade de São Paulo, Escola de Artes, Ciências e Humanidades, São Paulo, SP, Brazil

4 Universidade Presbiteriana Mackenzie, Centro de Ciências Biológicas e da Saúde, São Paulo, SP, Brazil

5 Universidade de São Paulo, Escola Superior de Agricultura 'Luiz de Queiroz', Departamento de Ciências Biológicas, Piracicaba, SP, Brazil

6 Author for correspondence: raflima@usp.br 


\section{Introduction}

One useful way to study tropical forests is via large permanent inventory plots (Condit 1998), specially designed for the study large-sized, long-lived organisms such as trees. Recently, numerous plots have been established in a variety of types of forests around the world (Losos et al. 2004). However, these permanent plots are restricted to particular types of soils, primarily oxisols and ultisols (Ashton 2004). Still, surprisingly diverse forests grow on a larger number of soil types, including relatively nutrient-poor, white-sand soils (Newbery 1991; Phillips et al. 1994). In Brazil, besides the widespread Amazon campinaranas (Anderson 1981), some coastal forests also grow on sandy soils (mainly spodosols), the Restinga forests. These forests are known to be lower and less species rich than surrounding rain forests, although species rich Restinga forests may also be found (César \& Monteiro 1995; Guedes et al. 2006; Negrelle 2006).

But what is the typical structure and composition of Restinga forests? How is it different from forests that grow on non-sandy soils? How clumped are trees of different species on such nutrient poor-soils? Is there any evidence of species being more associated to habitat characteristics than in forests on richer soils? The answer to these and many other questions are still unavailable because detailed accounts of Restinga forests are largely missing. Plots over 1-ha are rare (Assis et al. 2004; Negrelle 2006), and therefore there is not enough data to properly assess general community-level patterns, Restinga population distributions, habitat associations or other features related to the ecology of these forests. For instance, the occurrence of multi-stemmed trees, cited as being typical of Restinga species (Sugiyama 1998; Guedes et al. 2006), has never been properly assessed. In addition, this lack of knowledge also prevents a proper comparison of Restinga forests with other forest types.

Restinga forests are part of the Restinga vegetation complex (or simply Restinga), a typical feature of Brazilian coastal plains. By definition, it is the vegetation that grows over tertiary or quaternary marine sand deposits. So, although the Restinga forest may be seen as a climax formation in the Restinga complex, it is a very young type of forest, geologically speaking. Besides its young age, the limiting soil conditions makes it a very promising setting in which the mechanisms that control the floristic composition and structure of tropical forests can be better understand (Scarano 2009). For instance, a low degree of endemism is expected because soils are much younger than other forests on soils developed in situ (Anderson 1981). In this scenario, one may ask if the Restinga composition is the result of simple historical events or if there is local and specific ecological processes (e.g. competition, facilitation or herbivore pressure - Scarano 2002; Fine et al. 2009) that control species establishment and growth. Therefore, the study of tropical forests under such extreme conditions can give us a broader perspective on their structure, composition, and diversity.
In addition, Restingas are very important systems to physical and biological conservation of Atlantic Forest areas. Besides the more obvious important linked to the prevention of sea erosion, Restingas can shelter considerable populations of species that are rare in other Atlantic forest types (Scarano 2009). This type of vegetation is restricted to narrow spaces along the Atlantic Ocean coastline, places where human settlements are major and constant threats to biodiversity (Rocha et al. 2007). More specifically, high Restinga forests (HRF) represent one of the most rare and threatened vegetation types of the already deforested Brazilian Atlantic Forest (Ribeiro et al. 2009).

Aiming to describe and understand more precisely the composition, structure, diversity, and spatial patterning of Restinga forests at different scales, we present a study of a 10.24-ha plot established in the high Restinga forest of the Parque Estadual da Ilha do Cardoso (PEIC), at $25^{\circ} \mathrm{S}$ latitude. The main goal of this study was to detect general community-level patterns of the plot tree community. We evaluated several different characteristics of the community such as tree density, basal area, and species richness and how these characteristics vary among different tree size classes. We also assess the frequency and specificity of multi-stemmed individuals in the community. Spatial analyses were carried out for the most abundant species, aiming to describe general patterns of species aggregation.

\section{Methods}

\section{Study area}

This study was conducted in the Parque Estadual da Ilha do Cardoso (PEIC), a 13,500-ha continental island located in Cananéia County, in the extreme southern tip of São Paulo State, southeastern Brazil (Fig. 1). Although at $25^{\circ} \mathrm{S}$ latitude, the climate is tropical and wet with no dry season (mean annual water surplus= 1,330 mm - Af sensu Köppen (1948) climate classification). Mean annual temperature is $22.4{ }^{\circ} \mathrm{C}$ (average daily maximum and minimum are 26.1 and $18.0^{\circ} \mathrm{C}$ ), mean minimum temperature of the coldest month is $12.6^{\circ} \mathrm{C}$, and average annual precipitation is 2,261 $\mathrm{mm}$. Only one month (August) has an average precipitation below $100 \mathrm{~mm}$ and the average rainfall for the three driest months is $314 \mathrm{~mm}$ (DAEE/SP, 2010). Data collection was carried out in a 10.24 -ha $(320 \times 320 \mathrm{~m})$ permanent plot established in $2002\left(25^{\circ} 04^{\prime} 41^{\prime \prime} S\right.$ and $\left.47^{\circ} 55^{\prime} 53^{\prime \prime} \mathrm{W}\right)$, subdivided into 256 subplots of $20 \times 20 \mathrm{~m}\left(400 \mathrm{~m}^{2}\right)$. The terrain is flat (altitude between 3 and $8 \mathrm{~m}$ above sea level) and developed over the sedimentary rocks of the Cananéia Formation (Upper Pleistocene). The soils are young (around 5,000 years), sandy (90-100\%, mainly fine-grained sand), strongly acidic ( $\mathrm{pH}$ in water between 3.9-5.0), hydromorphic, and with variable content of organic matter (Gomes et al. 2007). The plot soil survey classified them as aquodic quartzipsamments (lower parts, periodic flooded), wet spodosols (arenic/oxyaquic 


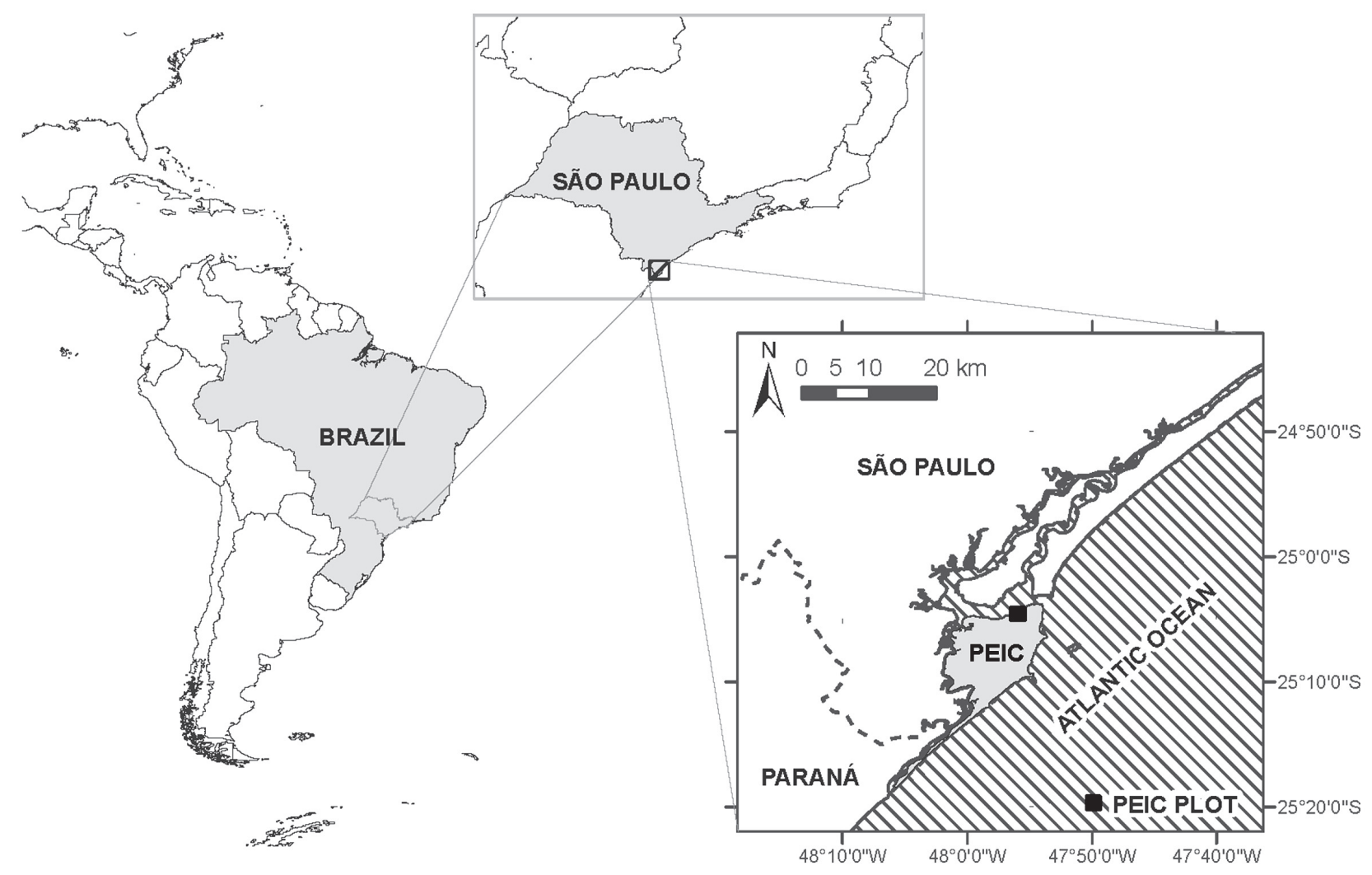

Figure 1. Location of the Parque Estadual da Ilha do Cardoso (PEIC) and the PEIC 10.24-ha forest plot.

alorthod and histic alaquod) and thionic histosols (terric sulfisaprists - soil maps, profiles and details on physical and chemical properties can be found in Gomes et al. 2007). The plot vegetation represents one type of the Atlantic Forest, the high Restinga forest (HRF), a type of forest which grows over marine sand deposits and is equivalent to Lowland tropical rain forest (Holdridge et al. 1971). Vegetation over marine sand deposits covers approximately $18 \%$ of the island. The PEIC has no main geographical barriers except rivers separating it from the continent, which is one of the largest and better conserved landscapes of the Atlantic Forest (Ribeiro et al. 2009). Therefore, there is no evidence of dispersal limitation from the continent and other forest types of the island. In addition, there is no evidence of any recent human disturbance inside the PEIC plot, although it is possible that low intensity selective timber extraction occurred before the establishment of the park in 1962.

\section{Tree census}

Tree census followed the Center for Tropical Forest Science protocol (Condit 1998) except that it only included individuals with stem girth at breast height $\geq 15 \mathrm{~cm}$, equivalent to diameter at breast height $(\mathrm{dbh}) \geq 4.8 \mathrm{~cm}$. All individuals were tagged, mapped and identified to the species level. The diameter of each stem of each individual was measured to the nearest $1 \mathrm{~mm}$ and the number of stems of multistemmed individuals (i.e. with ramifications of the trunk below $1.3 \mathrm{~m}$ ) was counted. Tree height was measured to the nearest $0.5 \mathrm{~m}$ for most individuals and was used to estimate mean and maximum canopy heights. Species identifications were based on several reference collections and the relevant literature. Vouchers were deposited in the Universidade de São Paulo (Campus Piracicaba) herbarium (ESA) under the collection numbers of D. Sampaio. We followed the APG II (2003) system. The plot was first censused in 2002 and then again in 2004/2005; because of improved species-level identifications in the second census, data presented here refer to the individuals found alive during the second census.

\section{Forest structure and diversity}

In addition to the total plot density and basal area, the relative values of density and basal area were calculated for each species following Mueller-Dombois \& Ellenberg (1974). Stems were assumed to have a cylindrical shape to calculate tree basal area. In order to assess forest stratification we divided the sample according to different diameter size classes: $\geq 4.8 \mathrm{~cm} ; \geq 10 \mathrm{~cm} ; \geq 20 \mathrm{~cm}$; and $\geq 30 \mathrm{~cm}$ dbh. For multi-stemmed individuals, the diameter of the largest stem was used to determine the size class. We estimated the maximum richness using different non-parametric estimators (e.g. Michaelis-Menten, first and second order Jackknife), performed using 5,000 randomizations by the EstimateS software (Colwell 2006). The choice of using the first order Jackknife to discuss the results was made empiri- 
cally, based on the number of samples required to estimate the total plot richness and on the tendency of stabilization of the curve, following Colwell and Coddington's (1994) recommendations. Average values of density, basal area, richness, singletons, and Fisher's alpha and Berger-parker index (Magurran 2004) per hectare were estimated from all possible 1-ha square plots that could be fit in the 10.24-ha plot ( $n=144$ plots). The number of singletons per hectare is used here as a practical definition of rare species and the Berger-parker index refers to the relative abundance of the most common species. All the analyses were completed for the four size classes in order to assess possible differences in the vertical structure of the forest.

\section{Multi-stemmed individuals}

The numbers of stems per individual were evaluated for each species, to detect if the distribution of the number of individuals in different stem categories ( 1 to 10 stems per individual) was significantly different than the distribution observed for the community as a whole. The distribution observed for each focal species was compared to 1000 random distributions, obtained by randomly selecting from the community a number of individuals equal to the abundance of the focal species in the plot. For each category of number of stem per individual, we observed the proportion of random distributions (simulations) smaller than the number observed for the species in the category. When this proportion was equal to or greater than $95 \%$, the observed number was considered to be different than the expected by chance for the whole community (randomization test sensu Manly 2006). To test if the species with the highest proportions of multi-stemmed individuals were also the most abundant species in the plot, we compared the density of each species that had more multi-stemmed individuals than expected by chance with the density of all other species in the plot. Simulation procedures were also used to run this test. In both analyses, we excluded some palms (Euterpe edulis, Geonoma schottiana and Syagrus romanzoffiana) that have strictly monopodial growth habits and one gymnosperm species (Podocarpus sellowii).

\section{Spatial distribution}

To describe the spatial patterns of species, the Morisita Index of Dispersion (ID, Krebs 1999) was calculated based on the $20 \times 20 \mathrm{~m}$ subplots for each species with more than 70 individuals ( $n=40$ species). The observed value of the index for each focal species was compared with a null model that assumed complete spatial randomness of the individuals (Poisson distribution). This model was generated from 1000 simulations for the same number of individuals of the focal species. For each simulation, the null ID value was calculated and the distribution of values obtained was used to calculate the probability of the type I error on the statistical inference (Manly 2006). This approach was only used in the $\geq 4.8$ and $\geq 10 \mathrm{~cm}$ dbh size classes because of the small number of individuals per species in the bigger size classes. The routines used to generate the null models of multi-stemmed individuals (described above) and of complete spatial randomness were developed in R ( $\mathrm{R}$ Development Core Team 2008) and are available upon request from the authors.

To explore spatial patterns at scales larger than $20 \mathrm{~m}$, we carried out spatial autocorrelation analyses. For the same 40 species with $n>70$, the Moran's index $(I)$ was calculated for different distance classes up to $200 \mathrm{~m}$ (correlograms, Legendre \& Legendre 1998) based on the distance between the $20 \times 20 \mathrm{~m}$ subplots. The global significance of the correlogram was tested using the Bonferroni method (Legendre \& Fortin 1989) and in cases of significant correlograms, the values of the coefficients were tested for each scale individually. This test was performed using a Monte Carlo permutation routine that assigned randomly the observed densities for each subplot 1000 times to construct the confidence envelopes around the null model at each given scale. Positive and significant values indicate positive autocorrelation at a given distance class, whereas negative and significant values indicate the opposite. The absence of significant values indicates a random or regular distribution at the given distance class. Finally, to illustrate the existing types of spatial distribution, species were separated into general patterns of spatial distribution (see results for patterns description). The assignment of species to each pattern was based on the visual inspection of the correlogram and of the distribution map of the species in the plot. The definition of patterns was subjective but we do believe that they are representative examples and that they may be useful to assess what mechanisms are influencing species distributions.

\section{Results}

\section{Forest diversity and composition}

We sampled 15,040 individuals that represented a total basal area of $290 \mathrm{~m}^{2}$ (Tab. 1). These individuals belonged to 45 families, 87 genera and 116 species. Based on this sample, a total of $126 \pm 3.1$ (Jackknife 1) tree species was estimated for the HRF of the PEIC. Fisher's alpha was 17.1 \pm 0.6 (Shannon= 3.58) for the entire plot, but the value was slightly greater when calculated for samples of 1-ha (17.9). In the 1-ha subsamples, the number of singletons (13.7 singletons $\mathrm{ha}^{-1}$ ) was greater than that obtained for the 10.24-ha plot (9 singletons). In contrast, the Berger-Parker index of dominance was more or less the same independent of the sample size. The rarefaction curve indicated 5.5 ha as the area at which $95 \%$ of the total richness was found. In addition, the number of singletons leveled-off around nine after about 6.5 ha.

Arecaceae was the most abundant family, followed by Myrtaceae, Lauraceae, Annonaceae and Rubiaceae. Together they accounted for $58.8 \%$ of the sampled individuals. The 
Table 1. Total and per hectare values of the main structure and diversity parameters in different size classes in a 10.24-ha plot of high restinga forest. $n=$ total number of individuals; $B A=$ Basal area; Singletons= species with only one individual in the sample. Brackets refer to the 2.5 and 97.5 percentiles of the distribution obtained from 144 one-hectare plots inside the 10.24-ha plot.

\begin{tabular}{|c|c|c|c|c|}
\hline \multirow[t]{2}{*}{ Parameter } & \multicolumn{4}{|c|}{ Size class $(\mathrm{cm})$} \\
\hline & $\geq 4.8$ & $\geq 10$ & $\geq 20$ & $\geq 30$ \\
\hline$n$ & 15,040 & 6,229 & 2,199 & 807 \\
\hline$n \mathrm{ha}^{-1}$ & $1,467.6[1292-1681]$ & $642.2[527-725]$ & $224.8[185-273]$ & $82.3[60-108]$ \\
\hline$B A\left(\mathrm{~m}^{2}\right)$ & 289.9 & 251.4 & 183.0 & 115.9 \\
\hline$B A \mathrm{ha}^{-1}$ & $27.99[25.2-33.2]$ & 24.61 [21.3-29.8] & $17.88[13.9-23.4]$ & $11.30[7.7-16.7]$ \\
\hline Species & 116 & 103 & 76 & 52 \\
\hline Species ha ${ }^{-1}$ & $79.1[65-89]$ & $62.3[50-70]$ & $38.7[29-47]$ & $17.1[9-26]$ \\
\hline Singletons & 9 & 11 & 12 & 19 \\
\hline Singletons $\mathrm{ha}^{-1}$ & $13.7[8-19]$ & $13.7[9-20]$ & $12.9[8-19]$ & $8.8[2-17]$ \\
\hline Fisher's alpha & $17.11 \pm 0.59$ & $17.53 \pm 0.71$ & $15.47 \pm 0.81$ & $12.72 \pm 0.92$ \\
\hline Fisher's alpha ha ${ }^{-1}$ & $17.93[14.2-21.1]$ & $17.14[12.3-20.1]$ & $13.64[8.4-14.5]$ & $6.76[2.8-12.4]$ \\
\hline Berger-Parker & 0.20 & 0.08 & 0.18 & 0.29 \\
\hline Berger-Parker ha-1 & $0.20[0.12-0.28]$ & $0.11[0.07-0.18]$ & $0.21[0.12-0.35]$ & $0.31[0.19-0.48]$ \\
\hline
\end{tabular}

most abundant species in the plot was Euterpe edulis with $293.8 \pm 154.9$ trees ha $^{-1}$, and a frequency of $99.6 \%$. The 40 most abundant species in the plot are listed in Tab. 2. $\mathrm{Ca}$ lophyllum brasiliense, Ocotea pulchella, Albizia pedicellaris, Tapirira guianensis, Euterpe edulis and Manilkara subsericea were the species with the largest contribution to basal area (50.2\%). Myrtaceae was the richest family (21\% of species), followed by Lauraceae (10\%), and Fabaceae (5\%). Twenty five families had just one species in the plot. The full list of species names and abundances from the 2004/2005 census can be found at http://ecologia.ib.usp.br/labtrop/doku. php?id=labtrop:01_projetos:02_pp:pp_peic:pp_peic\#lista_ de_espécies.

\section{Forest structure}

The increase in tree diameter from 4.8 to $10 \mathrm{~cm}$ resulted in the exclusion of 8,811 individuals, that is, almost three fifths of all individuals in the sample (58.6\%). In turn, the total number of singletons increased with the size class considered. There was a tendency for higher diversity and smaller dominance in the $\geq 10 \mathrm{~cm}$ size class (Tab. 1). With respect to dominance, there was a shift in the dominant (i.e. more-abundant species) species among the size classes. $\mathrm{Eu}$ terpe edulis was dominant in the size class $\geq 4.8 \mathrm{~cm}$, Ocotea pulchella was dominant in the mid-size classes $(\geq 10$ and $\geq 20 \mathrm{~cm}$ ) and Calophyllum brasiliense was dominant above $30 \mathrm{~cm} \mathrm{dbh}$. The six species with the greatest contribution to basal area (cited above) were also the most common species in the plot canopy (78.3\% of trees $\geq 30 \mathrm{~cm} \mathrm{dbh}$ ). Albizia pedicellaris attained the greater average and overall $\mathrm{dbh}$ in the plot (34.4 and $85.4 \mathrm{~cm}$, respectively), followed by Calophyllum brasiliense (mean $\mathrm{dbh}=33.1 \mathrm{~cm}$ ). Together, these two species accounted for $82 \%$ of trees $\geq 50 \mathrm{~cm}$ dbh in the plot. Besides these two species, only five others exceeded $50 \mathrm{~cm}$ dbh (i.e. Eugenia sulcata, Myrcia glabra, Manilkara subsericea, Ocotea pulchella, and Tapirira guianensis). All species with individuals present in the plot canopy ( $\mathrm{dbh} \geq$ $30 \mathrm{~cm}$ ) had individuals $<10 \mathrm{~cm}$ dbh. In contrast, 26 species did not exceed 15 cThere was considerable variance in abundance and, consequently, in species rank order among the different size classes (Tab. 2). Many species' (45\%) abundances gradually declined with increasing size class (e.g. Euterpe edulis, Xylopia langsdorffiana, Amaioua intermedia, Andira anthelmia and Schefflera angustissima). Small-sized species, as expected, declined drastically with an increase in size class ( $25 \%$ of species), with no or extremely low contributions to the $>20 \mathrm{~cm}$ dbh size class (e.g. Miconia cubatanensis, Marlierea racemosa, Guatteria australis, Garcinia gardneriana, Alibertia myrciifolia, and Ilex amara). Other species, however, presented a smoother decline in abundance with size classes, reflecting peaks of abundance at larger size classes (17.5\% of species) or abundance values more similar among classes (12.5\%). Ocotea pulchella, for instance, had more individuals $>40 \mathrm{~cm}$ than $<10 \mathrm{~cm} \mathrm{dbh}$, showing a peak of abundance between 20 and $25 \mathrm{~cm} \mathrm{dbh}$. Examples of these general patterns of species diameter distribution are illustrated in Fig. 2.

\section{Multi-stemmed individuals}

We found 84 species (72\%) and 1,623 individuals (10.8\%) with two or more stems (mean $\pm \mathrm{sd}$ : $1.17 \pm 0.60$ stems individual $\left.^{-1}\right)$. Only 233 trees $(1.5 \%)$ of 36 species $(31 \%)$ had more 
Table 2. The 40 most abundant species found in a 10.24-ha plot of high restinga forest and their correspondent abundance, aggregation (Morisita's index of dispersion) and distribution pattern (DP). In parentheses, the species rank order in the size classes considered (species with the same abundance received the same rank to avoid overestimation of the real number of ranks per size class). See text for more detail on the distribution patterns of species. Legend to distribution patterns: A - no spatial autocorrelation; B - small isolated patches; C - more than one clump forming large stripes or larger patches more or less isolated; D - big patches covering large areas of the plot; $\mathrm{E}-$ no evident pattern.

\begin{tabular}{|c|c|c|c|c|c|c|c|c|c|c|c|}
\hline \multirow{3}{*}{$\begin{array}{l}\text { Species and author } \\
\text { Euterpe edulis Mart. }\end{array}$} & \multicolumn{8}{|c|}{ Abundance (species rank) } & \multicolumn{2}{|c|}{ Morisita's index } & \multirow{3}{*}{$\begin{array}{l}\mathrm{DP} \\
\mathrm{D}\end{array}$} \\
\hline & \multicolumn{2}{|c|}{$\geq 4.8 \mathrm{~cm}$} & \multicolumn{2}{|c|}{$\geq 10 \mathrm{~cm}$} & \multicolumn{2}{|c|}{$\geq 20 \mathrm{~cm}$} & \multicolumn{2}{|c|}{$\geq 30 \mathrm{~cm}$} & \multirow{2}{*}{$\frac{\geq 4.8 \mathrm{~cm}}{1.192^{* * *}}$} & \multirow{2}{*}{$\frac{\geq 10 \mathrm{~cm}}{1.696^{* *}}$} & \\
\hline & 3008 & (1) & 109 & (19) & 8 & $(30)$ & 2 & $(28)$ & & & \\
\hline Xylopia langsdorffiana A. St.-Hil. \& Tul. & 946 & (2) & 136 & $(15)$ & 10 & $(32)$ & 3 & $(26)$ & $1.281^{* * *}$ & $1.813^{*+*}$ & $\mathrm{D}$ \\
\hline Amaioua intermedia Mart. & 837 & (3) & 400 & $(2)$ & 32 & $(17)$ & 1 & $(34)$ & $1.410^{* * *}$ & $1.431^{* * *}$ & B \\
\hline Schefflera angustissima (Marchal) Frodin & 574 & (4) & 287 & $(7)$ & 86 & $(7)$ & 23 & (6) & $1.219^{* * *}$ & $1.285^{* * *}$ & A \\
\hline Andira anthelmia (Vell.) J.F.Macbr. & 548 & (5) & 278 & $(8)$ & 34 & $(15)$ & 4 & (18) & $1.120^{* *}$ & $1.223^{* *}$ & $\mathrm{D}$ \\
\hline Ocotea pulchella (Nees) Mez & 537 & (6) & 518 & $(1)$ & 400 & $(1)$ & 171 & (2) & $1.839^{* * *}$ & $1.876^{* *+}$ & $\mathrm{D}$ \\
\hline Pera glabrata (Schott) Poepp. ex Baill. & 526 & (7) & 309 & $(6)$ & 50 & $(11)$ & 5 & $(15)$ & $1.400^{* * *}$ & $1.065^{\mathrm{ns}}$ & $\mathrm{D}$ \\
\hline Ternstroemia brasiliensis Cambess. & 526 & (7) & 384 & (3) & 45 & (13) & 7 & (11) & $3.167^{* * *}$ & $2.977^{*+*}$ & $\mathrm{C}$ \\
\hline Tapirira guianensis Aubl. & 505 & (9) & 357 & $(5)$ & 186 & $(3)$ & 93 & (3) & $1.375^{* * *}$ & $1.295^{* * *}$ & B \\
\hline Myrcia racemosa (O. Berg) Kiaersk. & 444 & $(10)$ & 72 & $(24)$ & 3 & $(50)$ & 1 & $(34)$ & $1.479^{* * *}$ & $2.504^{* * *}$ & $\mathrm{C}$ \\
\hline Calophyllum brasiliense Cambess. & 410 & $(11)$ & 365 & $(4)$ & 294 & $(2)$ & 230 & (1) & $1.237^{* * *}$ & $1.279^{* * *}$ & $\mathrm{E}$ \\
\hline Calyptranthes concinna DC. & 323 & $(12)$ & 187 & $(11)$ & 73 & $(8)$ & 12 & (7) & $1.979^{* * *}$ & $2.502^{* * *}$ & B \\
\hline Miconia cubatanensis Hoehne & 267 & (13) & 26 & $(44)$ & - & & - & & $2.732^{* * *}$ & - & $\mathrm{D}$ \\
\hline Ocotea aciphylla (Nees) Mez & 261 & $(14)$ & 140 & $(14)$ & 67 & $(9)$ & 10 & $(10)$ & $1.871^{* * *}$ & $1.868^{* *+}$ & $\mathrm{D}$ \\
\hline Pouteria beaurepairei (Glaz. \& Raunk.) Baehni & 251 & $(15)$ & 189 & $(10)$ & 59 & $(10)$ & 6 & (13) & $1.160^{*}$ & $1.282^{*}$ & $\mathrm{D}$ \\
\hline Garcinia gardneriana (Planch. \& Triana) Zappi & 250 & $(16)$ & 44 & $(31)$ & 4 & $(46)$ & 1 & $(34)$ & $2.114^{* * *}$ & - & $\mathrm{C}$ \\
\hline Psidium cattleianum Afzel. ex. Sabine & 238 & $(17)$ & 200 & (9) & 38 & $(14)$ & 2 & $(28)$ & $1.325^{* *}$ & $1.376^{* * *}$ & E \\
\hline Manilkara subsericea (Mart.) Dubard & 226 & $(18)$ & 170 & $(12)$ & 106 & $(5)$ & 44 & (5) & $1.863^{* * *}$ & $2.139^{* * *}$ & $\mathrm{D}$ \\
\hline Byrsonima ligustrifolia A. Juss. & 214 & (19) & 124 & $(17)$ & 24 & $(21)$ & - & $(54)$ & $2.876^{* * *}$ & $2.216^{* * *}$ & $\mathrm{E}$ \\
\hline Marlierea racemosa (Vell.) Kiaersk. & 190 & $(20)$ & 16 & $(56)$ & 3 & $(50)$ & 1 & $(34)$ & $4.021^{* * *}$ & - & $\mathrm{C}$ \\
\hline Eugenia sulcata Spring ex Mart. & 183 & $(21)$ & 99 & $(20)$ & 27 & $(20)$ & 5 & $(15)$ & $1.414^{* *}$ & $1.319^{\mathrm{ns}}$ & E \\
\hline Ilex theezans Mart. ex Reissek & 180 & $(22)$ & 154 & (13) & 92 & $(6)$ & 11 & $(8)$ & $5.784^{* * *}$ & $5.020^{* *+*}$ & B \\
\hline Aparisthmium cordatum Baill. & 179 & $(23)$ & 21 & $(50)$ & - & & - & & $3.150^{* * *}$ & - & B \\
\hline Balizia pedicellaris (DC.) Barneby \& J.W. Grimes & 163 & $(24)$ & 134 & $(16)$ & 107 & $(4)$ & 92 & $(4)$ & $1.125^{\mathrm{ns}}$ & $1.178^{\mathrm{ns}}$ & A \\
\hline Maytenus robusta Reissek & 154 & $(25)$ & 30 & $(39)$ & 3 & $(49)$ & - & & $2.488^{* * *}$ & - & $\mathrm{D}$ \\
\hline Myrcia sp. & 144 & $(26)$ & 43 & $(32)$ & - & & - & & $1.716^{* * *}$ & - & A \\
\hline Myrcia ilheosensis Kiaersk. & 134 & $(27)$ & 118 & $(18)$ & 48 & $(12)$ & 1 & $(34)$ & $5.229^{* * *}$ & $4.932^{* *+}$ & B \\
\hline Myrcia brasiliensis Kiaersk. & 119 & $(28)$ & 78 & $(21)$ & 31 & $(18)$ & 7 & $(11)$ & $1.349^{\mathrm{ns}}$ & $1.193^{\mathrm{ns}}$ & A \\
\hline Heisteria silvianii Schwacke & 115 & $(29)$ & 59 & $(26)$ & 12 & $(30)$ & 1 & $(34)$ & $3.085^{* * *}$ & - & $\mathrm{C}$ \\
\hline Myrcia multiflora (Lam.) DC. & 111 & $(30)$ & 78 & $(21)$ & 20 & $(24)$ & - & & $4.491^{* * *}$ & $5.479^{* * *+}$ & B \\
\hline Guatteria australis A. St.-Hil. & 104 & $(31)$ & 5 & $(72)$ & 2 & $(56)$ & 1 & $(34)$ & $1.721^{* *}$ & - & $\mathrm{E}$ \\
\hline Clusia criuva subsp. parviflora Vesque & 101 & $(32)$ & 74 & $(23)$ & 23 & $(22)$ & 1 & $(34)$ & $3.092^{* * *}$ & $2.843^{*+*}$ & $\mathrm{C}$ \\
\hline Ormosia arborea (Vell.) Harms & 95 & $(33)$ & 64 & $(25)$ & 23 & $(22)$ & 4 & $(18)$ & $1.204^{\mathrm{ns}}$ & - & A \\
\hline Myrcia bicarinata (O. Berg) D. Legrand & 94 & $(34)$ & 57 & $(28)$ & 7 & $(38)$ & 2 & $(28)$ & $10.015^{* * *}$ & - & B \\
\hline Matayba intermedia Radlk. & 93 & $(35)$ & 58 & $(27)$ & 34 & $(15)$ & 11 & $(8)$ & $1.676^{* *}$ & - & $\mathrm{C}$ \\
\hline Alibertia myrciifolia K. Schum. & 92 & $(36)$ & 4 & $(73)$ & - & & - & & $1.835^{* *}$ & - & $\mathrm{E}$ \\
\hline Myrcia glabra (O. Berg) D. Legrand & 80 & $(37)$ & 56 & $(29)$ & 31 & $(18)$ & 6 & (13) & $2.216^{* * *}$ & - & $\mathrm{C}$ \\
\hline Astrocaryum aculeatissimum (Schott) Burret & 79 & $(38)$ & 14 & $(59)$ & - & & - & & $3.656^{* * *}$ & - & $\mathrm{C}$ \\
\hline Ilex amara (Vell.) Loes & 74 & (39) & 22 & $(49)$ & - & & - & & $1.990^{* *}$ & - & A \\
\hline Posoqueria latifolia (Rudge) Schult. & 74 & $(39)$ & 35 & $(34)$ & 4 & $(46)$ & 1 & $(34)$ & $1.706^{+}$ & - & $\mathrm{E}$ \\
\hline
\end{tabular}

${ }^{*} p<0.05 ;{ }^{* *} p<0.01 ;{ }^{* * *} p=0.001$; ns $=$ not significant. 


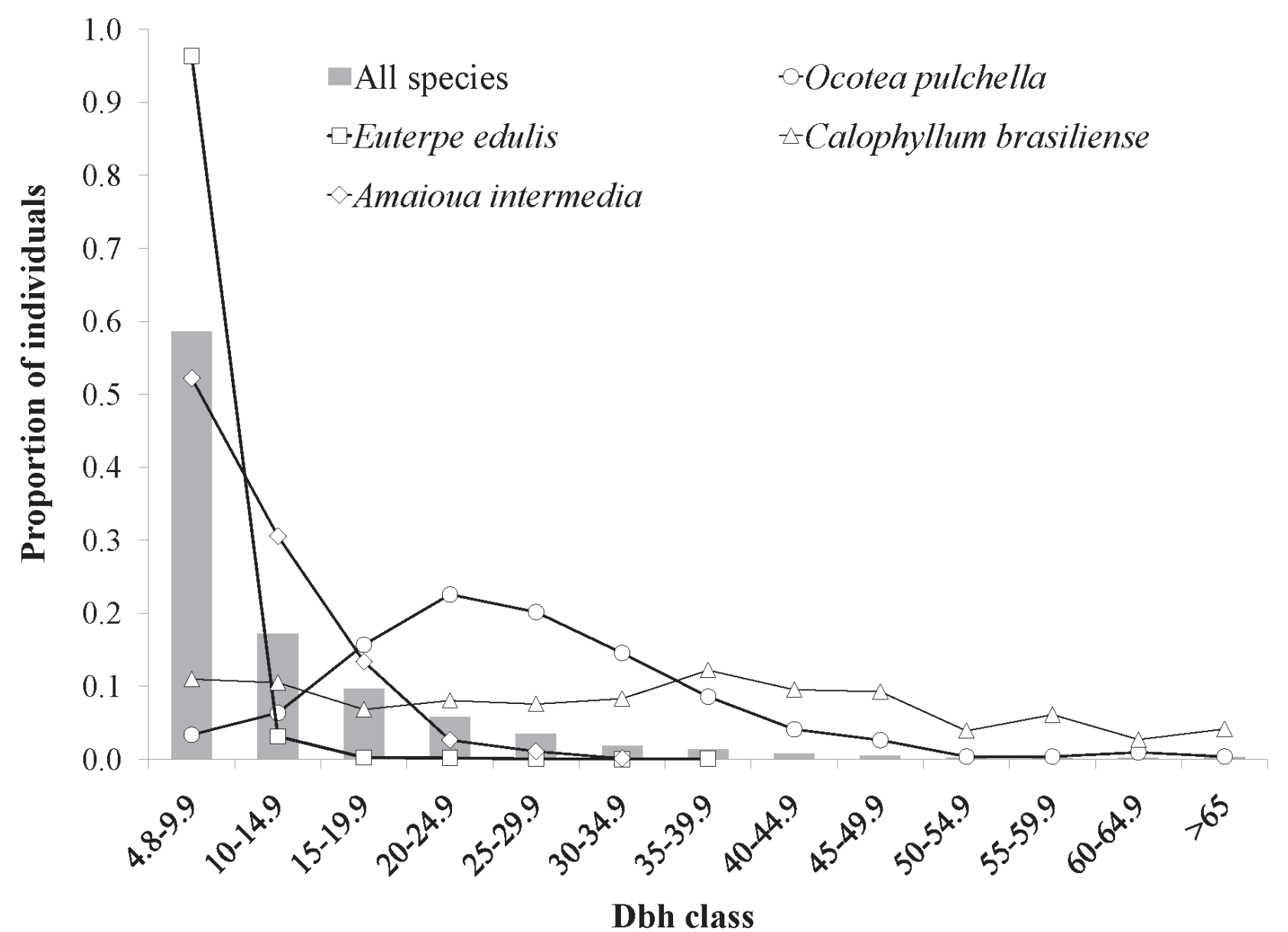

Figure 2. Overall size distribution and examples of species with different patterns of distribution in the PEIC plot. Dbh classes divided in $5 \mathrm{~cm}$ intervals.

than three stems. Eighteen species had significantly more stem ramifications than expected for the community as a whole, whereas another 26 species had fewer multi-stemmed individuals than expected. Marlierea racemosa had the highest number of stems (10) and also the highest proportion of multi-stemmed individuals (50.5\%). The mean abundance of species with significantly more stems per individual (185.1 \pm 256.7 trees) was marginally greater $(p=0.041)$ than the abundance of the other species in the plot (95.8 \pm 154.3 trees). Among the species with significantly fewer multi-stemmed individuals, only Blepharocalyx salicifolius did not have any multi-stemmed individuals in the plot. Some of the significantly less-ramified species had high densities in the plot $(n$ $<500$ ), such as Amaioua intermedia, Schefflera angustissima, Andira anthelmia, Ocotea pulchella, and Tapirira guianensis (Tab. 3), besides the monopodial palm Euterpe edulis.

\section{Spatial distribution}

Among the 40 most abundant species, dispersion patterns of three (Albizia pedicellaris, Myrcia brasiliensis and Ormosia arborea, pattern A in Tab. 2) were not significantly different from random at the $20 \mathrm{~m}$ scale. At larger scales, three other species (Schefflera angustissima, Myrcia sp. and Ilex amara) were also not clumped. All other species had clumped pat- terns at one or more distance classes, with Myrcia bicarinata, Myrcia ilheosensis, Myrcia multiflora, Marlierea racemosa and Ilex theezans having the highest aggregation indexes. In the size class $\geq 10 \mathrm{~cm}$ dbh, the random distribution was maintained for Albizia pedicellaris and Myrcia brasiliensis. The species Pera glabrata, clumped in the $\geq 4.8 \mathrm{~cm}$ size class, was not different from random in the $\geq 10 \mathrm{~cm}$ class. Other species were still clumped but had considerable increases (e.g. Myrcia racemosa and Myrcia multiflora) or decreases (e.g. Byrsonima ligustrifolia and Ilex theezans) in the Morisita index of dispersion in the size class $\geq 10 \mathrm{~cm}$ dbh. Visual inspection of the auto-correlograms and the distribution maps of the most abundant species in the plot ( $n>70$ individuals) suggested the existence of five general distribution patterns (Fig. 3 and Tab. 2). For certain species the individuals were clumped in small patches (e.g. Ilex theezans, pattern B), whereas others were concentrated in larger and specific areas of the plot (e.g. Ocotea aciphylla and Ternstroemia brasiliensis, patterns $\mathrm{C}$ and D). Besides a significant auto-correlation at some distances, eight species did not display an evident pattern of distribution (e.g. Calophyllum brasiliensis, pattern E). It is noteworthy that several Myrtaceae species (e.g. Myrcia ilheosensis, Myrcia multiflora and Myrcia bicarinata) were the most strongly clumped species on the plot. 
Renato Augusto Ferreira de Lima, Alexandre Adalardo de Oliveira, Adriana Maria Zanforlin Martini,

Daniela Sampaio, Vinícius Castro Souza and Ricardo Ribeiro Rodrigues

Table 3. Number of individuals per category of number of stems for species with more or less multi-stemmed individuals than expected by chance.

\begin{tabular}{|c|c|c|c|c|c|}
\hline \multirow{2}{*}{$\begin{array}{l}\text { Species } \\
\text { More multi-stemmed individuals than expected }\end{array}$} & \multicolumn{5}{|c|}{ Number of stems } \\
\hline & 1 & 2 & 3 & 4 & $>5$ \\
\hline Astrocaryum aculeatissimum (Schott) Burret & 58 & 13 & 8 & & \\
\hline Ecclinusa ramiflora Mart. & & & 1 & & \\
\hline Gordonia fruticosa (Schrader) H. Keng & 14 & & & & 1 \\
\hline Guarea macrophylla Vahl & 13 & 5 & & & \\
\hline Guatteria australis A. St.-Hil. & 78 & 18 & 5 & 2 & 1 \\
\hline Hirtella hebeclada Moric. ex A.P. DC. & 12 & 7 & 1 & 2 & \\
\hline Marlierea racemosa (Vell.) Kiaersk. & 94 & 37 & 31 & 16 & 12 \\
\hline Maytenus robusta Reissek & 106 & 28 & 15 & 5 & 1 \\
\hline Mollinedia schottiana (Spreng.) Perkins & 12 & 4 & 2 & 1 & 2 \\
\hline Myrceugenia myrcioides (Cambess.) O. Berg & 2 & & & 1 & \\
\hline Myrcia insularis Kiaersk. & 2 & & & & 1 \\
\hline Myrcia racemosa (O. Berg) Kiaersk. & 294 & 87 & 46 & 13 & 4 \\
\hline Myrcia sp. & 94 & 30 & 11 & 6 & 3 \\
\hline Ocotea aciphylla (Nees) Mez & 204 & 29 & 11 & 8 & 9 \\
\hline Ocotea pulchra (Nees) Mez & 43 & 8 & & & \\
\hline Ocotea venulosa (Nees) Mez & 37 & 5 & 1 & 1 & \\
\hline Ternstroemia brasiliensis Cambess. & 448 & 65 & 8 & 5 & \\
\hline Xylopia langsdorffiana A. St.-Hil. \& Tul. & 478 & 241 & 133 & 55 & 38 \\
\hline Less multi-stemmed individuals than expected & 1 & 2 & 3 & 4 & $>5$ \\
\hline Aiouea saligna Meisn. & 41 & 1 & & & \\
\hline Amaioua intermedia Mart. & 769 & 53 & 12 & 3 & \\
\hline Andira anthelmia (Vell.) J.F. Macbr. & 499 & 32 & 11 & 4 & 2 \\
\hline Aparisthmium cordatum Baill. & 163 & 11 & 3 & 2 & \\
\hline Balizia pedicellaris (DC.) Barneby \& J. W. Grimes & 161 & & 2 & & \\
\hline Blepharocalyx salicifolius (Kunth) O. Berg & 53 & & & & \\
\hline Calophyllum brasiliense Cambess. & 403 & 6 & 1 & & \\
\hline Calyptranthes concinna DC. & 306 & 16 & 1 & & \\
\hline Eugenia umbelliflora O. Berg & 63 & 3 & & & \\
\hline Garcinia gardneriana (Planch. \& Triana) Zappi & 246 & 4 & & & \\
\hline Heisteria silvianii Schwacke & 112 & 3 & & & \\
\hline Ilex theezans Mart. ex Reissek & 166 & 13 & 1 & & \\
\hline Jacaranda puberula Cham. & 55 & 2 & 1 & & \\
\hline Manilkara subsericea (Mart.) Dubard & 211 & 14 & & 1 & \\
\hline Myrcia brasiliensis Kiaersk. & 116 & 2 & & 1 & \\
\hline Myrcia glabra (O. Berg) D. Legrand & 76 & 1 & 1 & & \\
\hline Myrcia ilheosensis Kiaersk. & 127 & 6 & 1 & & \\
\hline Myrcia multiflora (Lam.) DC. & 111 & & 1 & & 1 \\
\hline Ocotea pulchella (Nees) Mez & 504 & 26 & 3 & 3 & \\
\hline Ormosia arborea (Vell.) Harms & 92 & 2 & 1 & & \\
\hline Pera glabrata (Schott) Poepp. ex Baill. & 510 & 12 & 3 & & 1 \\
\hline Posoqueria latifolia (Rudge) Schult. & 70 & 3 & 1 & & \\
\hline Pouteria beaurepairei (Glaz. \& Raunk.) Baehni & 230 & 16 & 3 & & 1 \\
\hline Rapanea venosa (A. DC.) Mez & 43 & 1 & & & \\
\hline Schefflera angustissima (Marchal) Frodin & 569 & 5 & & & \\
\hline Tapirira guianensis Aubl. & 481 & 19 & 5 & 2 & \\
\hline
\end{tabular}



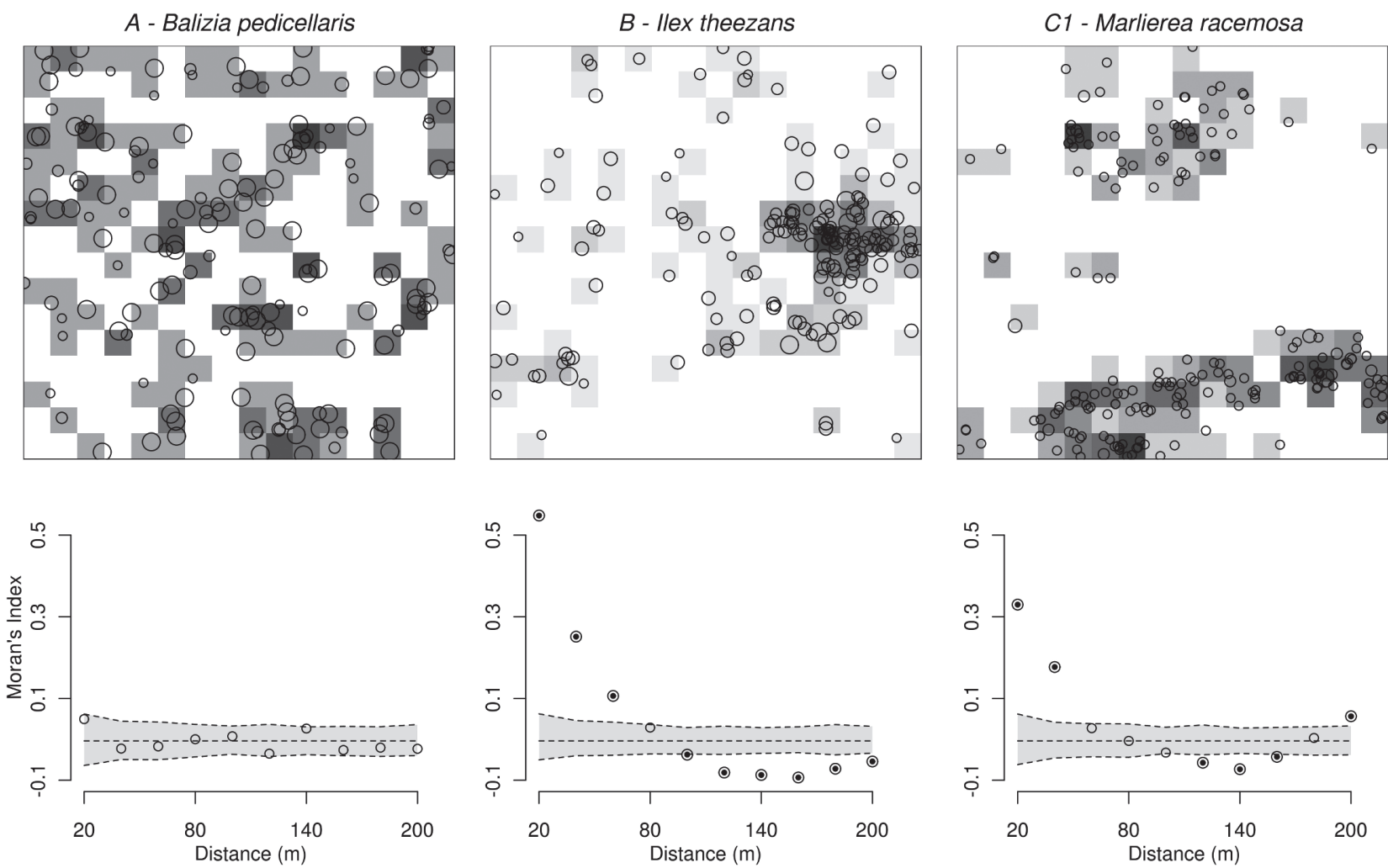

C2 - Ternstroemia brasiliensis

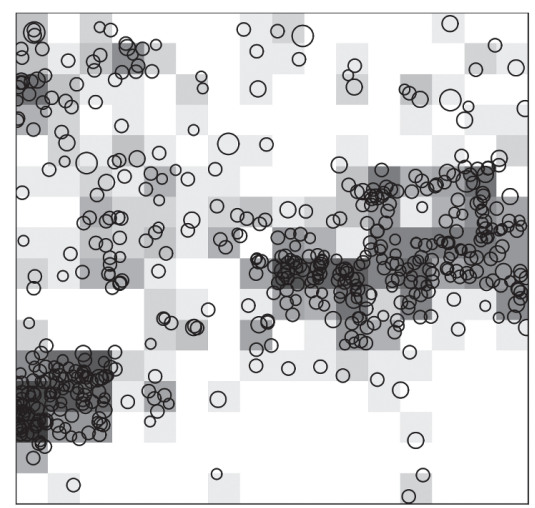

$D$ - Ocotea aciphylla
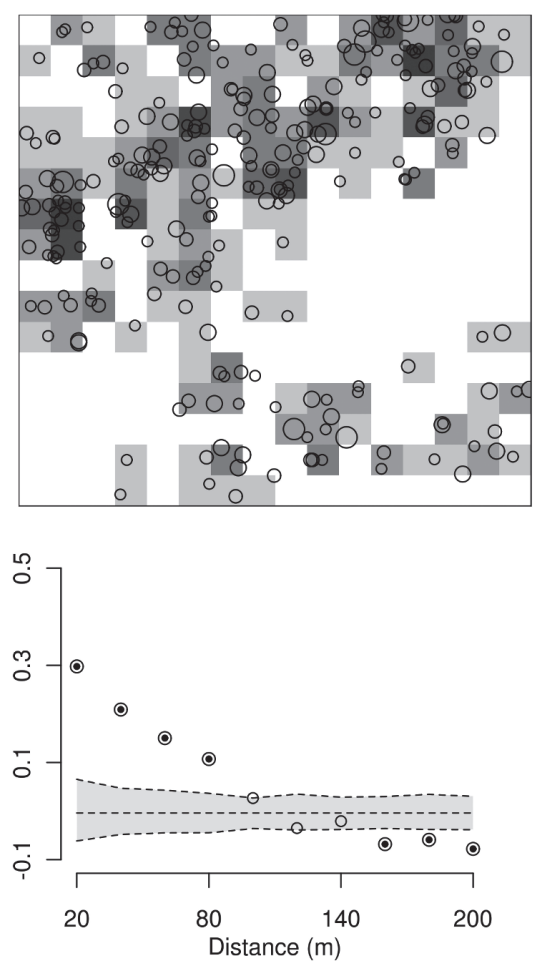

\section{E - Calophyllum brasiliense}
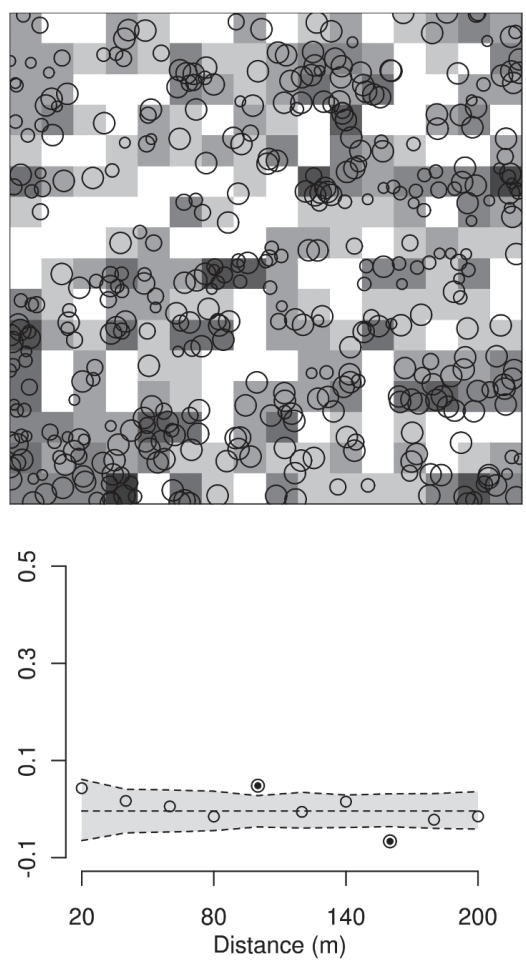

Figure 3. Illustrative maps of the general distribution patterns suggested for the most abundant tree species in the 256 subplots (20×20 m) surveyed. Circles vary in size according to tree size. More dark colors indicate subplots with higher values of abundance, while the white color indicate subplots with zero individuals of a given tree species. Legend to patterns: A - no spatial autocorrelation (A); B - small isolated patches (B); C - more than one clump forming large stripes (C1) or larger patches more or less isolated (C2); D - big patches covering large areas of the plot (D); E - and no evident pattern (E). 


\section{Discussion}

\section{Forest diversity and composition}

The mean richness obtained ( 79 species ha ${ }^{-1}$ ) was lower than other Brazilian sites of HRF (92 and 128 species ha $^{-1}$ Assis et al. 2004 and Negrelle 2006, respectively; note that both studies used non-contiguous plots). Even the studies with much smaller sampling efforts attained similar or higher species richness (César \& Monteiro 1995; Guedes et al. 2006). One possible explanation for this result may lie in the particularities of the PEIC plot substratum, which is young ( $<5000$ years), very acid, hydromorphic and periodically flooded (Gomes et al. 2007). Besides the little time that species had for colonization, such features impose important constraints on the establishment of some species (Dumont et al. 1990; Marques et al. 2009). Lower richness was also found when comparing trees $\geq 10 \mathrm{~cm}$ dbh of two nearby non-HRF sites (109 - Melo 2000; and ca. 108 species ha $^{-1}$ - R.A.F. Lima, unpublished data).

The number of rare species (i.e. singletons) per hectare represented $17 \%$ of the plot richness, a value quite similar to other HRFs (14 to 17\%, Assis et al. 2004; Negrelle 2006) and lower than that observed values for forests on non-sandy soils (> 23\% - Melo 2000, Melo et al. 2000; Guilherme et al. 2004; Losos 2004). In addition, Fisher's alpha were much smaller than in 10 other tropical forest plots (values from 23 to 181) evaluated by Condit et al. (2004), except by the Mudumalai dry deciduous forest plot (5.9). Therefore, lower richness, rarity and diversity may be characteristic to HRFs relative to forests on richer soils. However, studies with standardized sampling methods and in HRF on soils with different features (age, acidity and/or flooding regime) are still needed to test this suggestion.

Arecaceae was the most abundant family, a common finding in many other Atlantic Forests. Exceptions are found where there is illegal palm-heart harvesting (César \& Monteiro 1995; Guilherme et al. 2004; Guedes et al. 2006), an activity not seen inside the plot. Myrtaceae also deserves special mention because it harbored twice as many species as the second richest family of the plot. This pattern was not observed in other CTFS plots (Ashton et al. 2004), or inventories of forests on white-sand soils in South America (Phillips \& Miller 2002) and Asia (Proctor et al. 1983; Newbery 1991; Davies \& Becker 1996), where Myrtaceae does not exceed 7\% of the total tree richness. However, nearby Atlantic Forest types have similar richness per family, with similar or higher Myrtaceae richness (Melo et al. 2000; Guilherme et al. 2004), suggesting an important effect of the geographic region on the general pattern of HRF floristic composition.

To the best of our knowledge, this is the largest survey ever carried out in a high restinga forest or in any other forest on white-sand soils. Magurran (2004) has suggested that sample sufficiency is attained when the species ac- cumulation curve crosses the Michaelis-Menten model curve, which was observed around 4.4 ha. This also can be interpreted as the sampling area needed to confidently estimate the richness observed in the plot. According to the first and second order Jackknife estimators, these areas would be 3.4 and 2 ha, respectively. The suggestion of Colwell \& Coddington (1994) that sample sufficiency is attained when all species have at least two individuals proved to be impracticable because the number of singletons virtually leveled-off after about 6.5 ha. This indicates that the presence of naturally rare species $\left(\leq 1\right.$ trees $\left.\mathrm{ha}^{-1}\right)$ in the PEIC plot is not merely a sampling artifact. Therefore, the 10.24-ha plot was appropriate to describe the composition of the studied HRF, but it was insufficient to characterize the population structure of rare species. Anyhow, these results indicate the use of contiguous plots of at least 6 ha to properly assess species richness and composition of HRF on similar soils.

Forest structure - The PEIC plot had a density similar to other non-HRF Atlantic Forest sites (Melo 2000, R.A.F. Lima, unpublished data) but with less basal area. In addition, among the other 42 sites consulted (e.g. Philips et al. 1994; Losos et al. 2004), only four had basal areas smaller than the one found here, three of them also being found on whitesand soils. This result corroborates the connection between forest structure and soil properties suggested by Phillips et al. (1994) and Uhl \& Murphy (1981). The pattern found here was also found by other authors when comparing whitesand forests to other types of tropical forests (Proctor et al. 1983; Davies \& Becker 1996; Nebel et al. 2001; Miyamoto et al. 2003) and it is primarily due to the higher proportion of trees $<10 \mathrm{~cm}$ dbh and to the smaller proportion of large trees. In the PEIC plot the mean number of trees $\geq 60 \mathrm{~cm}$ dbh per hectare was six, whereas in other forest types it varied between eight and 33 trees (mean $\pm \mathrm{sd}: 19 \pm 7$, Losos et al. 2004). Three factors are probably impeding species to attain large sizes: low soil fertility, higher light availability at ground level, which may induce individuals to cease vertical growth earlier, and lower potential size of Restinga species (Luizão et al. 2007; Scarano 2009). Future studies monitoring Restinga species growth controlling these three factors would be particularly useful to better understand the mechanisms giving rise to structure in such forests.

The considerable change in species rank order among size classes, including changes in the most abundant species in the sample, confirms that the contribution of a given species also depends on the tree-diameter cutoff (Valencia et al. 2004; Kenfack et al. 2007). And these changes are not related exclusively to the presence of small-sized species in the understory. Different from expected, almost one third of the species did not have a constant decrease in the number of individuals with an increase in diameter. This result may be a remnant of recent sucessional changes in the community. For instance, species that had peaks of density in larger size classes (e.g. Ternstroemia brasiliensis, Ocotea pulchella, Myrcia ilheosensis, Ilex theezans) are also abun- 
dant in forest borders or in younger successional stages of Restinga vegetation of PEIC (Sugiyama 1998). On the other hand, species that had densities more constant among size classes were often emergent tree species (e.g. Calophyllum brasilense, Albizia pedicellaris, Manilkara subsericea), which may have regeneration strategies different from other species, including different mortality and growth rates and/ or seed production strategies (Clark \& Clark 1987; Swaine \& Hall 1988). So, the successional stage of the community (i.e. age of the substratum) and the regeneration strategies of its species are perhaps the two main determinants of the vertical composition and structure of HRFs.

\section{Multi-stemmed individuals}

The occurrence of multi-stemmed individuals has been noted by different authors as a common feature of Restinga species (Sugiyama 1998; Guedes et al. 2006) and as an important regeneration mechanism in Restinga forests (Assumpção \& Nascimento 2000). Indeed, $74 \%$ of the species showed at least one multi-stemmed individual in the PEIC plot, a proportion that was higher than the one found for three other types of tropical forests of southeastern Brazil (ca. 44-68\% - Lima et al., unpublished data). Nevertheless, the total number of multi-stemmed individuals was quite close to the numbers obtained for these forests, showing no evidence that this phenomenon is more common in the HRF tree individuals. Why there would be more species with multi-stemmed individuals in the HRF than in other comparable types of forest remains unclear.

There was evidence that the average abundance of species with more multi-stemmed individuals was larger than other species, suggesting that this trait may influence species survival. For instance, a larger number of stems per individual may be beneficial in terms of light interception efficiency and survival after physical damage, an advantage which is well documented for species able to survive and resprout after being damaged (Paciorek et al. 2000; Martini et al. 2008). However, among the ten most abundant species in the plot $(n>400)$ only three had a greater number of stems than expected. Hence, the ability to produce multi-stemmed trees is not mandatory for successful establishment, at least in terms of density. In addition, resprouting after damage is not the only reason why individuals have more than one stem. Multi-stemmed individuals, for instance, may be linked to a higher availability of light that would stimulate a premature ramification. In any case, our prediction is that species with a high proportion of multi-stemmed individuals would show a smaller number of stems per individual in shaded environments. And if the species also have a lower density of individuals, then we could start to infer about the competitive benefits of multi-stemmed individuals.

\section{Spatial distribution}

Although some studies indicate that species' dispersion patterns are predominantly aggregated (e.g. Armesto et al. 1986), there is little information on multi-species patterns of dispersion at different scales. Li et al. (2009) found that $92 \%$ of species were aggregated at scales $<50 \mathrm{~m}$, and Condit et al. (2000) found similar results for scales $<30 \mathrm{~m}$. These scales correspond to our patterns B and C, but in the PEIC plot $25 \%$ of the most abundant species were aggregated at scales $>70 \mathrm{~m}$. Clumped distributions are generally the result of association to discrete habitats, patterns of seed dispersal, interspecific interactions (e.g. competition, facilitation), and/or expanding or contracting distributions (Hutchings 1997; Valencia et al. 2004; Law et al. 2009; Li et al. 2009), whereas large clumps can be related to environmental heterogeneity. In the PEIC plot, species distributed over large patches (patterns $C$ and $D$ ) suggested species associated with habitat, probably soil. Species with distributions practically opposite in respect to particular places were relatively common and intriguing (e.g. Ocotea pulchella and Ternstroemia brasiliensis). Such places may indicate (un)favorable abiotic conditions where more stress-tolerants do well, or where more competitive species (e.g. ground bromeliads) may exclude others. Or it may indicate an association with resource availability (nutrients or light). It is noteworthy that similar distribution patterns can be generated from different mechanisms (Harms et al. 2001).

In forests with restrictive soil conditions, such as the HRF, patterns of aggregation are particularly interesting. Higher aggregation in the larger size classes, for instance, would indicate a greater degree of habitat association (Condit et al. 2000). Examples of this result in the PEIC plot are Myrcia racemosa and Myrcia multiflora. The opposite could indicate dispersal-limited species, such as Byrsonima ligustrifolia and Ilex theezans. Although the number of individuals in the larger size classes was limited to properly assess such processes, this approach should be extended to a larger number of species, perhaps including individuals $<4.8 \mathrm{~cm} \mathrm{dbh}$. Condit et al. (2000) suggested that changes in the patterns of aggregation among size classes are small (although the proportion of species with significant values of aggregation presented by these authors was considerably lower for $\mathrm{dbh} \geq 10 \mathrm{~cm}$ ). Examples from other types of forests also suggest that the abiotic conditions are not able to explain the distribution of the majority of forest species (Harms et al. 2001; Valencia et al. 2004). Nevertheless, in the PEIC plot we believe that there is a higher degree of habitat association, particularly regarding the type of soil, flooding regime, and canopy gap distribution that combined generate very distinct habitats for tree establishment.

\section{Concluding remarks}

The structural features observed in the Atlantic HRF were very close to those found for other white-sand forests around the world. Common in South America and Asia, and known by several local names (e.g. heath forests, campinaranas, kerangas, varillal alto - Anderson 1981), white-sand forests develop on acid, sandy soils with low availability of nutrients (Proctor et al. 1983; Ashton 2004; Luizão et al. 2007). These features act simultaneously to 
generate forests whose characteristics are shorter stature, lower species diversity, and roots more concentrated in the superficial soil horizons (Davies \& Becker 1996; Miyamoto et al. 2003; 2007). For these reasons, we recognize the Atlantic HRF as a type of white-sand forest. Although forest structure and probably functioning are similar among white-sand forests, species composition seems to be linked to local biogeographical issues. This is in accordance with the Walter's biome classification (Walter 1986), in which the HRF should be classified as a Psammobiome I, i.e. a pedobiome within the Tropical Rain Forest Zonobiome, which is functionally and structurally determined by the sandy soil condition. Finally, we do believe that this similarity may be extended to other Neotropical forests over white-sand soils, such as the Brazilian muçunungas (Simonelli et al. 2008) or the 'river' HRF of Peru (Nebel et al. 2001).

\section{Acknowledgements}

We thank the project "Diversidade, dinâmica e conservação em Florestas do Estado de São Paulo: 40 ha de parcelas permanentes" (Process n: 99/09635-0, Fundação de Amparo à Pesquisa do Estado de São Paulo - FAPESP) and Petrobrás (Process $n^{\circ}: 0050.0023163 .06 .4$ ) for financial support. The first author was supported by a grant from the "Coordenação de Aperfeiçoamento de Pessoal de Nível Superior" (CAPES - Demanda Social program). We also thank the PEIC administration (Instituto Florestal - SP) and the help of taxonomic experts, namely Evelyn Lucas, Fiorella Mazine, Marcos Sobral, Inês Cordeiro, João Baitello, Luís Bernacci, Milton Groppo Jr., Reinaldo Monteiro and Sérgio Romaniuc. Finally, we thank Jerome Chave, Stuart Davies, Kyle Harms, Egbert Leigh Jr., and Flaviana Maluf for their valuable comments.

\section{References}

Anderson, A.B. 1981. White-sand vegetation of Brazilian Amazonia. Biotropica 13: 199-210.

APG (Angiosperm Phylogeny Group) 2003. An update of the angiosperm phylogeny group classification for the orders and families of flowering plants: APG II. Botanical Journal of the Linnean Society 141: 399-436

Armesto, J.J.; Mitchell, J.D. \& Villagran, C. 1986. A comparison of spatial patterns of trees in some Tropical and Temperate Forests. Biotropica 18: 1-11.

Ashton, P.S. 2004. Soils in the tropics. Pp. 57-68. In: Losos, E.C. \& Leigh Jr. E.G. (Eds). Tropical forest diversity and dynamism: Findings from a large-scale plot network. Chicago, University of Chicago Press.

Ashton, P.S. \& CTFS Work Group. 2004. Floristics and vegetation of the forest dynamics plots. Pp. 90-102. In: Losos, E.C. \& Leigh Jr. E.G. (Eds). Tropical forest diversity and dynamism: Findings from a large-scale plot network. Chicago, University of Chicago Press.

Assis, A.M.; Pereira, O.J. \& Thomaz, L.D. 2004. Fitossociologia de uma floresta de restinga no Parque Estadual Paulo César Vinha, Setiba, município de Guarapari (ES). Revista Brasileira de Botânica 27: 349-361.

Assumpção, J. \& Nascimento, M.T. 2000. Estrutura e composição florística de quatro formações vegetais de Restinga no Complexo Lagunar Grussaí/Iquipari, São João da Barra, RJ, Brasil. Acta Botanica Brasilica 14: 301-315.
César, O. \& Monteiro, R. 1995. Florística e fitossociologia de uma Floresta de Restinga em Picinguaba (Parque Estadual da Serra do Mar), município de Ubatuba - SP. Naturalia 20: 89-105.

Clark, D.B. \& Clark, D.A. 1987. Population ecology and microhabitat distribution of Dipteryx panamensis, a Neotropical rain forest emergent tree. Biotropica 19: 236-244.

Colwell, R.K. 2006. EstimateS: statistical estimation of species richness and shared species from samples. version 8. http://purl.oclc.org/estimates. (Accessed in 25/01/06)

Colwell, R.K. \& Coddington, J.A. 1994. Estimating terrestrial biodiversity through extrapolation. Philosophical Transactions of the Royal Society B 345: 101-11Condit, R. 1998. Tropical forest census plots: methods and results from Barro Colorado Island, Panama and a comparison with other plots. Berlin, Springer-Verlag.

Condit, R.; Ashton, P.S. \& Baker, P. 2000. Spatial patterns in the distribution of tropical tree species. Science 288: 1414-1418.

Condit, R. \& CTFS Work Group. 2004. Species-area relationships and diversity measures in forest dynamics plots. Pp. 79-89. In: Losos, E.C. \& Leigh Jr. E.G. (Eds). Tropical forest diversity and dynamism: Findings from a large-scale plot network. Chicago, University of Chicago Press.

DAEE/SP. 2007. Banco de Dados Pluviométricos do Estado de São Paulo. Disponível em: $<$ http://www.daee.sp.gov.br/hidrometeorologia/ bancodados.htm.>. (Acesso em: 03/02/10).

Davies, S.J. \& Becker, P. 1996. Floristic composition and stand structure of mixed dipterocarp and heath forests in Brunei Darussalam. Journal of Tropical Forest Science 8: 542-569.

Dumont, J.F.; Lamotte, S. \& Kahn, F. 1990. Wetland and upland forest ecosystems in Peruvian Amazonia: plant species diversity in the light of some geological and botanical evidence. Forest Ecology and Management 33/34: 125-139.

Fine, P.V.A.; Mesones, I. \& Coley, P.D. 2009. Herbivores promote habitat specialization by trees in Amazonian forests. Science 305: 663-665.

Gomes, F.H.; Vidal-Torrado, P.; Macías, F.; Gherardi, B. \& Perez, X.L.O. 2007. Solos sob vegetação de restinga na Ilha do Cardoso (SP). I Caracterização e classificação. Revista Brasileira de Ciência do Solo 31: 1563-1580.

Guedes, D.; Barbosa, L.M. \& Martins, S.E. 2006. Composição florística e estrutura fitossociológica de dois fragmentos de floresta de restinga no Município de Bertioga, SP, Brasil. Acta Botanica Brasilica 20: 299-311.

Guilherme, F.A.G.; Morellato, L.P. \& Assis, M.A. 2004. Horizontal and vertical tree community structure in a lowland Atlantic Rain Forest, Southeastern Brazil. Revista Brasileira de Botânica 27: 725-737.

Harms, K.E.; Condit, R.; Hubbell, S.P. \& Foster, R.B. 2001. Habitat associations of trees and shrubs in a 50-ha Neotropical forest plot. Journal of Ecology 89: 947-959.

Holdridge, L.R.; Grenke, W.C.; Hatheway, W.H.; Liang, T. \& Tosi, J.A. Jr. 1971. Forest environments in tropical life zones: a pilot study. Oxford. Pergamon Press.

Hutchings, M.J. 1997. The structure of plant populations. Pp. 325-358. In: Crawley, M.J. (Ed.). Plant ecology. Oxford, Blackwell Scientific.

Kenfack, D.; Thomas, D.W.; Chuyong, G. \& Condit, R. 2007. Rarity and abundance in a diverse African forest. Biodiversity and Conservation 16: $2045-2074$.

Köppen, W.P. 1948. Climatología: con un estudio de los climas de la tierra. México DC, Fondo de Cultura Económica.

Krebs, C.J. 1999. Ecological methodology. 2nd ed. New York, AddisonWesley Longman.

Law, R.; Illian, J.; Burslem, D.F.R.P.; Gratzer, G.; Gunatilleke, C.V.S. \& Gunatilleke, I.A.U.N. 2009. Ecological information from spatial patterns of plants: insights from point process theory. Journal of Ecology 97: 616-628.

Legendre, P. \& Legendre, L. 1998. Numerical ecology. 2nd ed. Amsterdam, Elsevier Science BV.

Legendre, P. \& Fortin, M.J. 1989. Spatial pattern and ecological analysis. Vegetatio 80: 107-138.

Li, L.; Huang, Z.; Ye, W.; Cao, H.; Wei, S.; Wang, Z.; Lian, J.; Sun, I-F.; Ma, K. \& He, F. 2009. Spatial distributions of tree species in a subtropical forest of China. Oikos 118: 495-502. 
Losos, E.C. 2004. Habitat specialization and species rarity. Pp. 103-106 In: Losos, E.C. \& Leigh Jr. E.G. (Eds). Tropical forest diversity and dynamism: Findings from a large-scale plot network. Chicago, University of Chicago Press.

Losos, E.C. \& CTFS Work Group. 2004. The structure of tropical forests. Pp. 69-78. In: Losos, E.C. \& Leigh Jr. E.G. (Eds). Tropical forest diversity and dynamism: Findings from a large-scale plot network. Chicago, University of Chicago Press.

Luizão, F.J.; Luizão, R.C.C. \& Proctor, J. 2007. Soil acidity and nutrient deficiency in central Amazonian heath forest soils. Plant Ecology 192: 209-224.

Magurran, A.E. 2004. Measuring biological diversity. Oxford, Blackwell Publishing.

Martini, A.M.Z.; Lima, R.A.F.; Franco, G.A.D.C. \& Rodrigues, R.R. 2008. The need for full inventories of tree modes of disturbance to improve forest dynamics comprehension: An example from a semideciduous forest in Brazil. Forest Ecology and Management 255: 1479-1488.

Manly, B.F.J. 2006. Randomization, bootstrap and Monte Carlo methods in biology. 3rd edn. London. Chapman and Hall/ CRC Press.

Marques, M.C.M.; Burslem, D.F.R.P.; Britez, R.M. \& Silva, S.M. 2009. Dynamics and diversity of flooded and unflooded forests in a Brazilian Atlantic rain forest: a 16-year study. Plant Ecology \& Diversity 2: 57-64.

Melo, M.M.R.F. 2000. Demografia de árvores em Floresta Pluvial Tropical Atlântica, Ilha do Cardoso, SP, Brasil. PhD thesis. Universidade de São Paulo. São Paulo.

Melo, M.M.R.F.; Oliveira, R.J.; Rossi, L.; Mamede, M.C.H. \& Cordeiro, I. 2000. Estrutura de um trecho de Floresta Atlântica de Planície na Estação Ecológica Juréia-Itatins, Iguape, SP, Brasil. Hoehnea 27: 299-322.

Miyamoto, K.; Suzuki, E.; Kohyama, T.; Seino, T.; Mirmanto, E. \& Simbolon, H. 2003. Habitat differentiation among tree species with small-scale variation of humus depth and topography in a tropical heath forest of Central Kalimantan, Indonesia. Journal of Tropical Ecology 19: 43-54.

Miyamoto, K.; Rahajoe, J.S.; Kohyama, T. \& Mirmanto, E. 2007. Forest structure and primary productivity in a Bornean heath forest. Biotropica 39: 35-42.

Mueller-Dombois, D. \& Ellenberg, H. 1974. Aims and methods of vegetation ecology. New York, John Wiley and Sons.

Nebel, G.; Kvist, L.P.; Vanclay, J.K.; Christensen, H.; Freitas, L. \& Ruíz, J. 2001. Structure and floristic composition of flood plain forests in the Peruvian Amazon I. Overstory. Forest Ecology and Management 150: $27-57$.

Negrelle, R.R.B. 2006. Composição florística e estrutura vertical de um trecho de Floresta Ombrófila Densa de Planície Quaternária. Hoehnea 33: 261-289.

Newbery, D.M.C. 1991. Floristic variation within kerangas (heath) forest: re-evaluation of data from Sarawak and Brunei. Vegetatio 96: 43-86.
Paciorek, C.J.; Condit, R.; Hubbell, S.P. \& Foster, R.B. 2000. The demographics of resprouting in tree and shrub species of a moist tropical forest. Journal of Ecology 88: 765-777.

Phillips, O. \& Miller, J.S. 2002. Global patterns of plant diversity: Alwyn H. Gentry's forest transect data set. St. Louis, Missouri Botanical Garden Press.

Phillips, O.L.; Hall, P.; Gentry, A.H.; Sawyer, S.A. \& Vazquez, R. 1994. Dynamics and species richness of tropical rain forests. Proceedings of the National Academy of Science 91: 2805-2809.

Proctor, J.; Anderson, J.M.; Chai, P. \& Vallack, H.W. 1983. Ecological studies in four contrasting lowland rain forests in Gunung Mulu National Park, Sarawak: I. Forest environment, structure and floristics. Journal of Ecology 71: 237-260.

R Development Core Team (2008) R: A language and environment for statistical computing. http://www.R-project.org (Accessed in $12 / 11 / 2008$ ).

Ribeiro, M.C.; Metzger, J.P.; Martensen, A.C.; Ponzoni, F.J. \& Hirota, M.M. 2009. The Brazilian Atlantic Forest: How much is left, and how is the remaining forest distributed? Implications for conservation. Biological Conservation 142: 1141-1153.

Rocha, C.F.D.; Bergallo, H.G.; van Sluys, M.; Alves, M.A.S. \& Jamel, C.E. 2007. The remnants of restinga habitats in the Brazilian Atlantic Forest of Rio de Janeiro state, Brazil: habitat loss and risk of disappearance. Brazilian Journal of Biology 67: 263-273.

Scarano, F.R. 2002. Structure, function and floristic relationships of plant communities in stressful habitats marginal to the Brazilian Atlantic Rainforest. Annals of Botany 90: 517-524.

Scarano, F.R. 2009. Plant communities at the periphery of the Atlantic rain forest: Rare-species bias and its risks for conservation. Biological Conservation 142: 1201-1208.

Simonelli, M.; Souza, A.L.; Peixoto, A.L. \& Silva, A.F. 2008. Floristic composition and structure of the tree component of a muçununga forest in the Linhares Forest Reserve, Espírito Santo, Brazil. Memoirs of the New York Botanical Garden 100: 351-370.

Sugiyama, M. 1998. Estudo de florestas da restinga da Ilha do Cardoso, Cananéia, São Paulo, Brasil. Boletim do Instituto de Botânica 11: 119-159.

Swaine, M.D. \& Hall, J.B. 1988. The mosaic theory of forest regeneration and the determination of forest composition in Ghana. Journal of Tropical Ecology 4: 253-269.

Uhl, C. \& Murphy, P.G. 1981. Composition, structure, and regeneration of a Tierra Firme forest in the Amazon basin of Venezuela. Tropical Ecology 22: 219-237.

Valencia, R.; Foster, R.B.; Villa, G.; Condit, R.; Svenning, J.-C.; Hernández, C.; Romoleroux, K.; Losos, E.; Magård, E. \& Balslev, H. 2004. Tree species distributions and local habitat variation in the Amazon: large forest plot in eastern Ecuador. Journal of Ecology 92: 214-229.

Walter, H. 1986. Vegetação e zonas climáticas: tratado de ecologia global. São Paulo, EPU. 